\title{
Akutni koronarni sindrom
}

\author{
Miodrag Ostojić, Milika Ašanin, Zorana Vasiljević Pokrajčić, Jovan Peruničić, \\ Milan Nedeljkovic, Goran Stanković, Siniša Stojković, Milan Dobrić
}

Klinika za kardiologiju, Klinički centar Srbije; Medicinski fakultet, Univerzitet u Beogradu

$\mathrm{R}$ azličite prezentacije akutnog koronarnog sindroma (AKS) dele isti patofiziološki supstrat. Glavni simptom koji inicira dijagnozu je bol u grudima, ali se klasifikacija bolesnika bazira na elektrokardiogramu (EKG). U skladu sa tim, postoje dve kategorije bolesnika:

Bolesnici sa tipičnim akutnim bolom u grudima i perzistentnom (>20 minuta) elevacijom ST segmenta. Ovo se naziva AKS sa ST elevacijom (STE-AKS). Većina ovih bolesnika će na kraju da razvije infarkt miokarda sa ST elevacijom (STEMI).

Bolesnici sa akutnim bolom u grudima ali bez perzistentne elevacije ST segmenta (NSTE-AKS). Oni imaju depresiju ST segmenta ili inverziju T talasa, aplatirane T talase, ili nemaju EKG promene pri prvoj prezentaciji.

STEMI je u Srbiji češći nego NSTE-AKS. Bolesnici sa STEMI imaju nešto veći hospitalni mortalitet nego oni sa

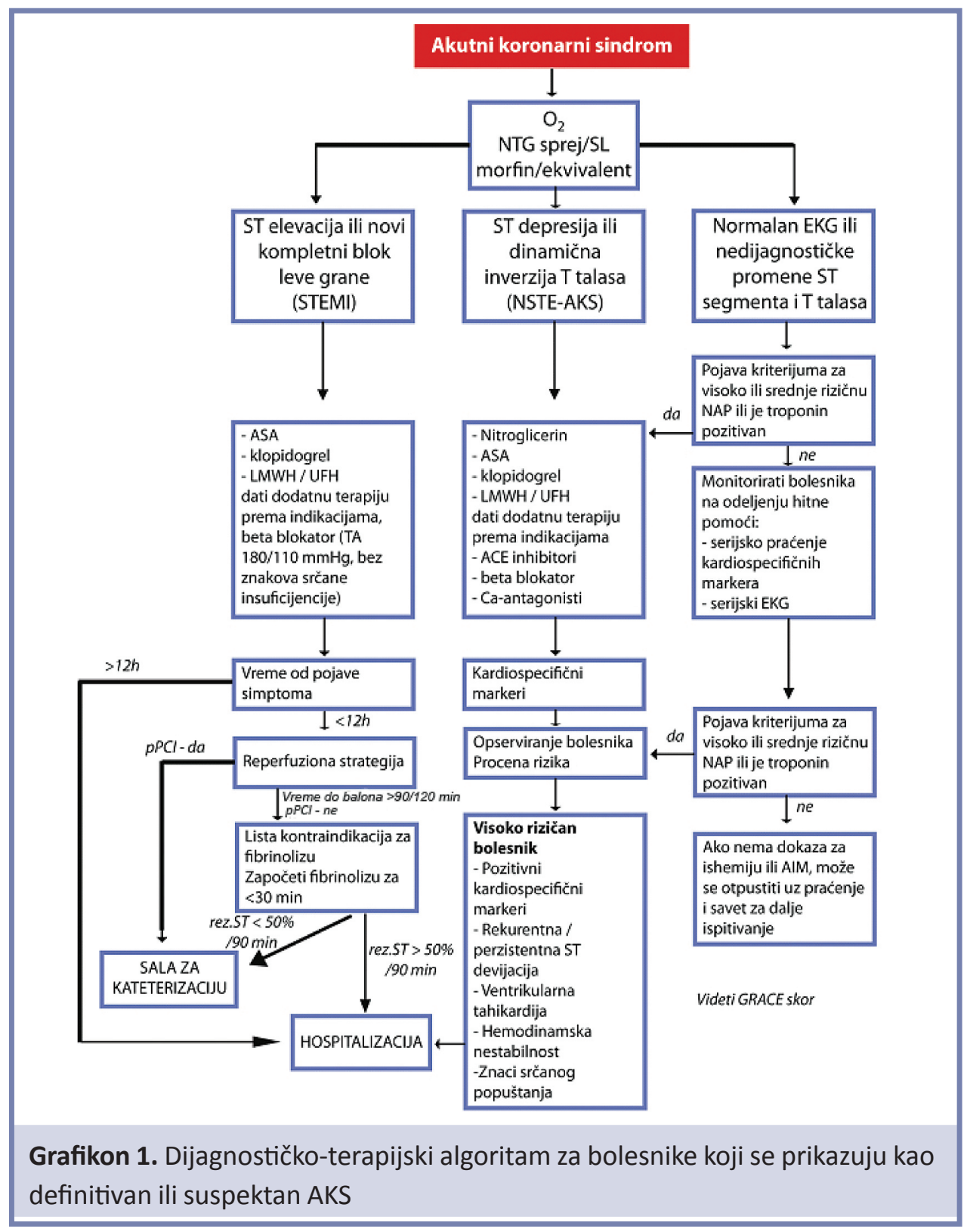

Kontakt osoba: Miodrag Ostojić, Klinika za kardiologiju, Klinički centar Srbije, Koste Todorovic 8, 11000 Beograd, Srbija 
NSTE-AKS (7\% prema 5\%), ali posle 6 meseci vrednosti mortaliteta kod oba stanja su veoma slični ( $12 \%$ odnosno $13 \%)$.

AKS je manifestacija ateroskleroze kojoj obično prethodi akutna tromboza, izazvana rupturom ili erozijom aterosklerotskog plaka, sa pratećom vazokonstrikcijom ili bez nje, uzrokujući iznenadno i kritično smanjenje u krvnom protoku. U STEMI tromb je bogat fibrinom $\mathrm{i}$ najčešće potpuno okluzivan, dok je u NSTE-AKS uglavnom trombocitni i delimično ili intermitentno okluzivan. Kako tromb raste, delovi tromba se otkidaju i može doći do embolizacije koronarne mikrocirkulacije. Tako mogu nastati male zone miokardne nekroze, što može imati za posledicu porast kardijalnih troponina.

$\mathrm{Na}$ Grifikonu 1. prikazan je dijagnostičko-terapijski algoritam za bolesnike koji se prikazuju kao definitivan ili suspektan AKS.

\section{Infarkt miokarda sa elevacijom ST segmenta}

Pri planiranju i sprovođenju revaskularizacije kod bolesnika sa STEMI postoji 5 strateških ciljeva:

1. Da se kod bolesnika sa STEMI odmah razmišlja o mehaničkoj reperfuziji, a u slučaju njene nemogućnosti o prehospitalnoj trombolizi (u odsustvu kontraindikacija) (klasa preporuke I, nivo dokaza A).

2. Ordiniranje antitrombocitnih lekova u prehospitalnim uslovima odmah po postavljanju dijagnoze (ASA, i lekovi iz grupe tienopiridina: klopidogrel ili tiklopidin, kao i prasugrela ili tikagrelora kada budu registrovani u Srbiji) (ASA - klasa preporuke I, nivo dokaza B; klopidogrel - klasa preporuke I, nivo dokaza C; prasugrel - klasa preporuke I, nivo dokaza B; tikagrelor - klasa preporuke I, nivo dokaza B).

3. Da se bolesnik transportuje do sale za kateterizaciju. Praksa da se bolesnik transportuje u urgentni prijem ili koronarne jedinice centara koji imaju salu za kateterizaciju je stručna greška (klasa preporuke III, nivo dokaza A), osim u izuzetnim slučajevima (npr. potreba za neodložnom terapijom koja se ne može pružiti u sali za kateterizaciju). Nedopustivo je transportovati takvog bolesnika i u ustanovu bez sale za kateterizaciju, jer se pokazalo da i sekundarni transport dovodi do velikih zakašnjenja. Popunjavanje „Reperfuzione liste za STEMI” (videti Grafikon 2.) usmerava ekipu da sa bolesnikom ide centripetalno - ka sali, a ne centrifugalno - od sale za kateterizaciju (klasa preporuke I, nivo dokaza C). Takođe, reperfuziona lista omogućava praćenje preduzetih mera za lečenje bolesnika, i to sukcesivno na svakoj etapi. Iz nje se može tačno rekonstruisati i ukupno ishemijsko vreme (od početka simptoma - do otvaranja za infarkt odgovorne arterije). Upravo ukupno ishemijsko vreme ima veliki prognostički značaj.

4. Podrazumeva se da treba da postoji rezervna pripravna ekipa HMP koja će zbrinjavati bolesnike na teritoriji sa koje je dežurna ekipa transportovala bolesnika sa STEMI do sale za kateterizaciju, u periodu dok je ova ekipa odsutna (klasa preporuke I, nivo dokaza C).
5. Napraviti nacionalni registar bolesnika sa akutnim koronarnim sindromom (klasa preporuke I, nivo dolaza C).

Reperfuzija je bitna kod bolesnika sa STEMI i ako se uradi u toku prvog sata od nastanka simptoma, može elektrokardiografski da ",abortira" infarkt miokarda u oko $25 \%$ slučajeva. Reperfuziona strategija određuje se zavisno od: trajanja simptoma do prvog medicinskog kontakta (odnosno postavljanja dijagnoze na EKG-u; ne čeka se nalaz biohumoralnih markera miokardne nekroze!), starosti bolesnika, veličine infarkta, telesne težine bolesnika, sklonosti ka hemoragičnim komplikacijama, kao i dostupnosti da se uradi pPCl u roku od 90 do $120 \mathrm{~min}$. U prehospitalnim uslovima bitno je proceniti koja je reperfuziona strategija primenljiva kod svakog pojedinačnog bolesnika. Procena primenljive strategije kod svakog pojedinačnog bolesnika se vrši prema Tabeli 4.1. Pošto za PCI u STEMI praktično ne postoje apsolutne kontraindikacije, vrlo je važno odmah proceniti da li bolesnik može da ima efikasnu pPCl unutar 90 , odnosno $120 \mathrm{~min}$. Ukoliko ne postoje uslovi za brzu i efikasnu pP$\mathrm{Cl}$, vrši se trijaža bolesnika za prehospitalnu trombolizu (jer je dokazano da je prehospitalna tromboliza zbog manjeg kašnjenja u odnosu na hospitalnu trombolizu znatno efikasnija). Ukoliko postoje indikacije za prehospitalnu trombolizu prelazi se na listu za proveru kontraindikacija (Tabela 4.2).

Ukoliko ne postoje kontraindikacije, treba započeti trombolizu unutar 30 min od postavljanja dijagnoze STEMI (snimanje i tumačenje EKG-a) (klasa preporuke Ila, nivo dokaza A). Transport bolesnika do automobila treba da bude na kardiološkoj stolici ili nosilima (od trenutka postavljanja dijagnoze STEMI bolesnik ne treba da napravi nijedan dodatni napor). U kolima HMP pacijent mora biti na nosilima sa podignutim uzglavljem. Svi lekovi daju se isključivo intravenski, supkutano ili oralno; LEKOVE NE DAVATI INTRAMUSKULARNO! Bitno je da se vodi protokol kako celokupne date terapije tako i izabranog puta do sale za kateterizaciju (videti Grafikon 4.2).

Bolesnici sa manjim infarktom, stariji od 75 god i sa povećanim rizikom od krvavljenja, a koji se prezentuju u prva $2 \mathrm{~h}$ od početka simptoma, treba da budu podvrgnuti pPCl u roku od $120 \mathrm{~min}$. Kod ove populacije dozvoljava se veće vreme kašnjenja (ne mora u toku 90 min jer je kod starijih bolesnika rizik od trombolize veći, a brzina nekroze miokarda je nešto sporija nego kod mlađih). Veći rizik od hemoragijskih komplikacija pri trombolizi postoji kod bolesnika: u starijoj životnoj dobi, ženskog pola, niske telesne težine, sa bubrežnom insuficijencijom, na terapiji sa više antitrombotika (duža $i$ istovremena upotreba ASA i OAK), visokim krvnim prtiskom na prijemu, sa cerebrovaskualrnim oštećenjima, što bi trebalo razmotriti naročito ako se kao fibrinolitik daje streptokinaza.

Ukoliko se na teritoriji gde se zbrinjava bolesnik nalazi sala za pPCl, lekar HMP mora uzeti u obzir ukupno potrebno vreme do započinjanja intervencije (a ne samo vreme transporta do sale koja može da bude zauzeta drugom započetom intervencijom), jer vreme odlaganja reperfuzije ne znači samo vreme u kome je bolesnik 
Tabela 1. Reperfuziona strategija zavisno od vremena od početka simptoma (sa klasama preporuka i nivoima dokaza) $)^{1,2}$

\begin{tabular}{|c|c|c|c|c|c|}
\hline $\begin{array}{c}\text { Trajanje simptoma do prvog } \\
\text { medicinskog kontakta }\end{array}$ & Može na PCl za 90 min & \multicolumn{2}{|c|}{ Ne može na PCl za 90 min } \\
\hline$<2$ h (veliki infarkt)* & $\mathrm{PCl}$ & $\mathrm{I}$ & $\mathrm{A}$ & prehospitalna tromboliza & Ila \\
\hline
\end{tabular}

\begin{tabular}{|c|c|c|c|c|c|}
\hline $\begin{array}{c}\text { Trajanje simptoma do prvog } \\
\text { medicinskog kontakta }\end{array}$ & Može na PCl za 120 min & \multicolumn{2}{|c|}{ Ne može na PCl za 120 min } \\
\hline$<2 \mathrm{~h}$ (mali infarkt)** & $\mathrm{PCl}$ & $\mathrm{I}$ & $\mathrm{A}$ & prehospitalna tromboliza & Ila \\
\hline
\end{tabular}

\begin{tabular}{|c|c|c|c|c|}
\hline $\begin{array}{l}\text { Trajanje simptoma do prvog } \\
\text { medicinskog kontakta }\end{array}$ & Može & $20 \mathrm{~min}$ & \multicolumn{2}{|c|}{ Ne može na $\mathrm{PCl}$ za 120 min } \\
\hline \multirow{2}{*}{$>2 \mathrm{~h}$ do $12 \mathrm{~h}$} & \multirow{2}{*}{$\mathrm{PCl}$} & \multirow{2}{*}{ I } & $\begin{array}{c}\text { - prehospitalna tromboliza } \\
\text { (ako <6 h od početka } \\
\text { simptoma - TNK) }\end{array}$ & Ila \\
\hline & & & $\begin{array}{l}\text { - hospitalna tromboliza } \\
\text { (ako >6 h od početka } \\
\text { simptoma - alteplaza) }\end{array}$ & Ila \\
\hline
\end{tabular}

\begin{tabular}{|c|c|c|c|c|c|}
\hline $\begin{array}{c}\text { Trajanje simptoma do prvog } \\
\text { medicinskog kontakta }\end{array}$ & \multicolumn{2}{|c|}{ Može na PCI } & \multicolumn{2}{c|}{ Ne može na PCI } \\
\hline$>12 \mathrm{~h}$ & $\mathrm{PCl}$ & Ila & $\mathrm{C}$ & $\begin{array}{c}\text { Koronarna jedinica } \\
\text { (+/-tromboliza, PCl, } \\
\text { OMT prema proceni) }\end{array}$ & $\mathrm{I}$ \\
\hline
\end{tabular}

* Veliki IM: prednji, prednji prošireni i anterolateralni

** Mali IM: inferiorni, izolovani posteriorni i visoki lateralni

Tabela 2. Lista za proveru kontraindikacija za prehospitalnu trombolizu

APSOLUTNE KONTRAINDIKACIJE prvo DA - odustani

Prethodna intrakranijalna hemoragija ili CVI nepoznate etiologije

Ishemični moždani udar u poslednjih 6 meseci

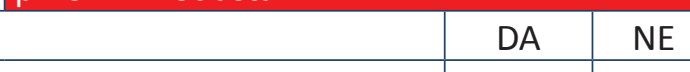

Poznati intrakranijalni maligni tumori (primarni ili metastatski)

Sumnja na aortnu disekciju

Aktivno krvarenje ili sklonost ka krvarenju (ne računajući menstrualni ciklus)

Krvarenje iz GIT-a u poslednje 4 nedelje

Značajna zatvorena povreda, operacija lica i glave unutar prethodne 3 nedelje

Nekompresibilne punkcije (npr. biopsija jetre, lumbalna punkcija)

\begin{tabular}{|c|c|}
\hline DA & NE \\
\hline DA & NE \\
\hline DA & NE \\
\hline DA & NE \\
\hline DA & NE \\
\hline DA & NE \\
\hline DA & NE \\
\hline
\end{tabular}

\begin{tabular}{|c|c|c|}
\hline RELATIVNE KONTRAINDIKACIJE & & \\
\hline TIA u prethodnih 6 meseci & $\mathrm{DA}$ & NE \\
\hline Hipertenzija u trenutku merenja (sist. TA > 180 mmHg ili dijast. TA > 110 mmHg) & DA & NE \\
\hline Demencija ili poznata intrakranijalna oboljenja & DA & NE \\
\hline Uznapredovale bolesti jetre & DA & NE \\
\hline Traumatska ili produžena (> $10 \mathrm{~min}$ ) kardiopulmonalna reanimacija & DA & NE \\
\hline Skorašnje (unutar 2-4 nedelje) unutrašnje krvarenje & DA & NE \\
\hline Punkcija krvnih sudova kod kojih se ne može uraditi kompresija & DA & NE \\
\hline $\begin{array}{l}\text { Streptokinaza: prethodno primanje (> } 5 \text { dana do godinu dana), ili prethodne alergijske reakcije } \\
\text { na ovaj lek }\end{array}$ & DA & NE \\
\hline Trudnoća i porođaj unutar jedne nedelje & DA & NE \\
\hline Aktivni peptički ulkus & DA & NE \\
\hline Bolesnik uzima antikoagulantne lekove: više vrednosti INR-a & DA & NE \\
\hline Infektivni endokarditis & DA & NE \\
\hline
\end{tabular}


transportovan do sale za kateterizaciju. Ovo vreme obuhvata zbirno vreme za pripremu bolesnika za transport od trenutka urađenog EKG-a, transport do automobila HMP, vremenske i saobraćajne uslove, udaljenost kateterizacione jedinice, kao i vreme potrebno za prijem ovih bolesnika i ulazak u salu (ili aktiviranje i pristizanje pripravne ekipe za pPCl). Potrebno je da postoji kontakt telefon sa kolegama u kateterizacionoj jedinici kako bi se pripravna ekipa pozvala i dobila potvrda da je sala slobodna i spremna. Ukoliko je moguće ispoštovati predviđeno vreme i uslove, lekar ordinira svu terapiju za STEMI osim trombolitika.

Ako je transport do sale za kateterizaciju nemoguć u ukupnom vremenu od 90 do 120 min (vreme proteklo od prvog EKG-a u prehospitalnim uslovima do otvaranja koronarne arterije) lekar HMP je dužan da ordinira prehospitalnu trombolizu, ukoliko ne postoje kontraindikacije.

Ukoliko HMP ne poseduje trombolitik, a vreme do otvaranja koronarne arterije u sali za kateterizaciju je duže od 90 do 120 min, obaveza lekara je da najavi dolazak bolesnika sa STEMI u najbližu koronarnu jedinicu kako bi ciljno vreme do započinjanja trombolitičke terapije od prvog medicinskog kontakta bilo do $30 \mathrm{~min}$. Ukoliko nije moguće dati trombolizu unutar $30 \mathrm{~min}$, potrebno je učiniti sve da se ona primeni što ranije, odnosno da kašnjenje bude što manje.

Bolesnik se transportuje uz OBAVEZAN EKG-monitoring, kao i monitoring svih vitalnih parametara.

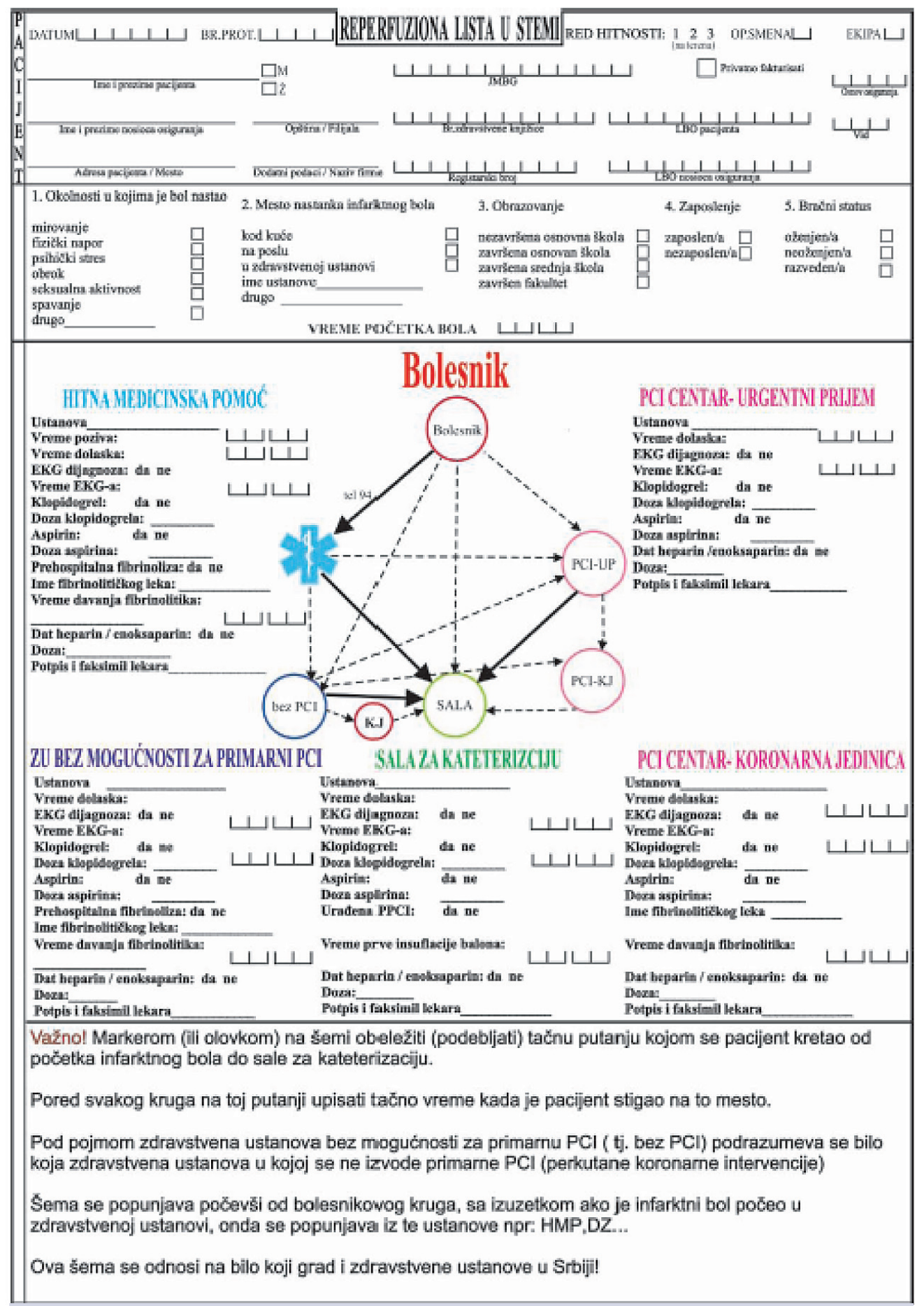

Grafikon 2. Reperfuziona lista za STEMI 


\section{Bolesnici sa STEMI koji su zakasnili za ranu $\mathrm{pPCl}$}

Bolesnici sa STEMI koji se lekaru jave između 12 i 24h, a moguće i do 60h od početka simptoma, čak i ukoliko su u trenutku postavljanja dijagnoze bez bola u grudima i stabilne hemodinamike, mogu i dalje imati korist od rane koronarografije i eventualno $\mathrm{PCl}^{3,4}$. Smatra se da bolesnici bez bola u grudima i bez inducibilne ishemije miokarda, sa okludiranom infarktnom arterijom, a koji se lekaru jave između 3. i 28. dana od početka simptoma, nemaju koristi od eventualne $\mathrm{PCI}^{5,6}$. Stoga su, od onih bolesnika koji se jave lekaru nekoliko dana nakon početka simptoma i koji već imaju formirane Q-zupce u elektrokardiogramu, jedino bolesnici sa rekurentnom anginom i/ili dokumentovanom rezidualnom ishemijom i dokazanom vijabilnošću velike teritorije miokarda kandidati za mehaničku revaskularizaciju?

\section{Preporuke za izvođenje primarne $\mathrm{PCl}$}

- Tokom primarne $\mathrm{PCl}(\mathrm{pPCl})$ izvodi se intervencija samo na leziji odgovornoj za infarkt (eng. culprit lesion) (klasa preporuke Ila, nivo dokaza B).

- Preporučuje se izvođenje manuelne tromboaspiracije (klasa preporuke Ila, nivo dokaza A).

- Preporuke za primenu antiagregacione i antikoagulantne terapije prikazane su u Tabeli 5.1.
- Kardiogeni šok - bez vremenskog ograničenja za $\mathrm{pPCl}$, uz preporuku za revaskularizaciju svih kritičnih lezija koje su pogodne za PCl (klasa preporuke I, nivo dokaza B).

- IABP - preporučuje se njena primena kod svih hemodinamski nestabilnih bolesnika (posebno kod bolesnika sa kardiogenim šokom i mehaničkim komplikacijama) (klasa preporuke I, nivo dokaza C).

\section{Preporuke za medikamentnu terapiju tokom hospitalizacije i nakon otpusta iz bolnice}

Preporučuje se nastavak dvojne antiagregacione terapije (aspirin i klopidogrel) koja je indikovana 9-12 meseci čak i kod bolesnika koji nisu imali nijedan vid reperfuzije (pPCl ili fibrinoliza), a nakon toga aspirin doživotno, zatim statini bez obzira na nivo lipida (sa ciljem da LDL bude manji od 1,8 mmol/L), a ukoliko nema kontraindikacija, preporučuje se terapija beta blokatorima i ACE inhibitorima.

\section{Nestabilna angina pektoris i infarkt miokarda bez elevacije ST segmenta ${ }^{8}$}

Radna dijagnoza AKS bez ST elevacije (NSTE-AKS) bazira se na merenju troponina i na kraju može da se kvalifikuje kao infarkt miokarda bez ST elevacije (NSTEMI) ili kao nestabilna angina pektoris (Grafikon 3 i 4).

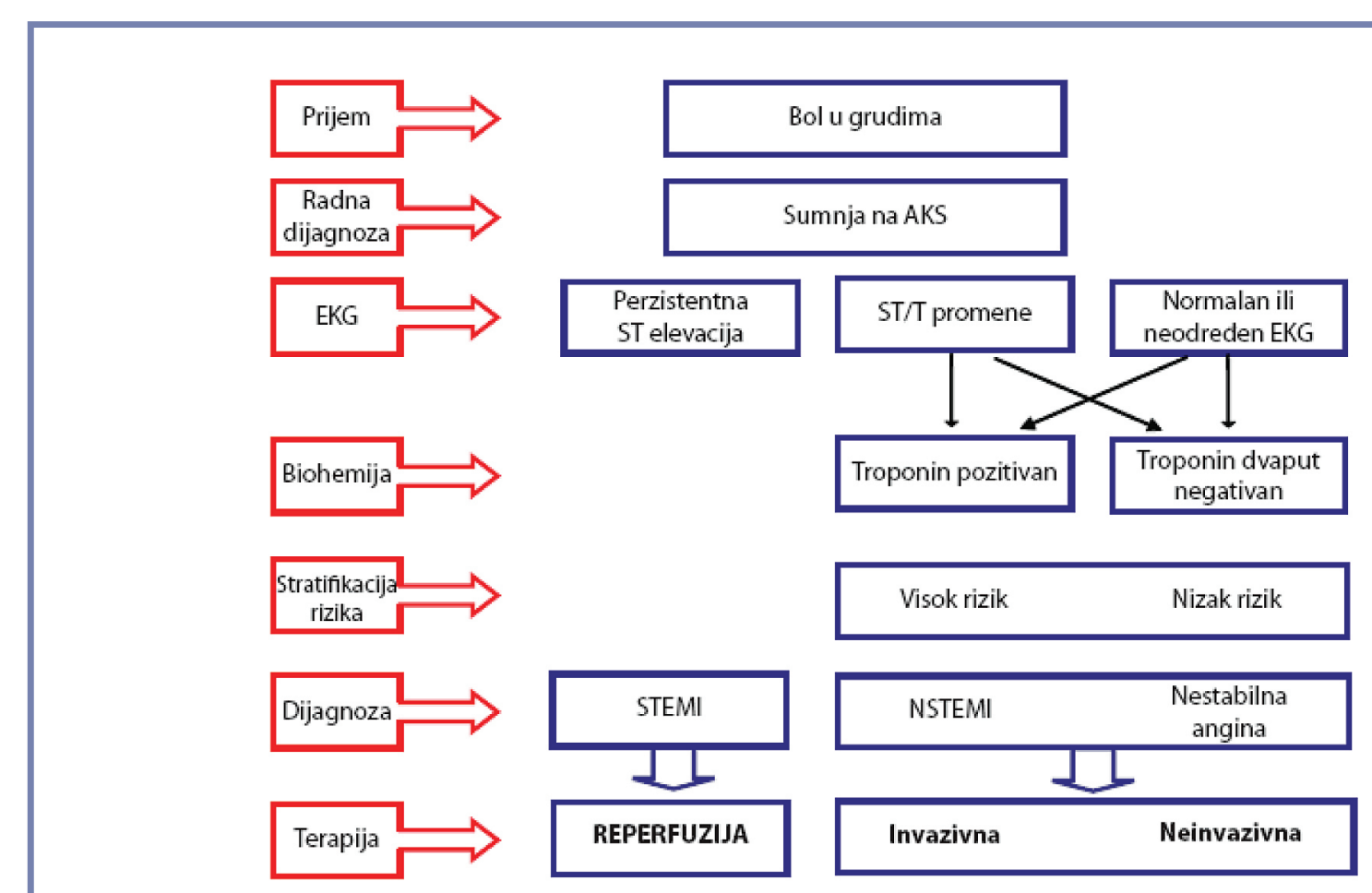

Grafikon 3. Spektar akutnih koronarnih sindroma 
Akutni bol u grudima

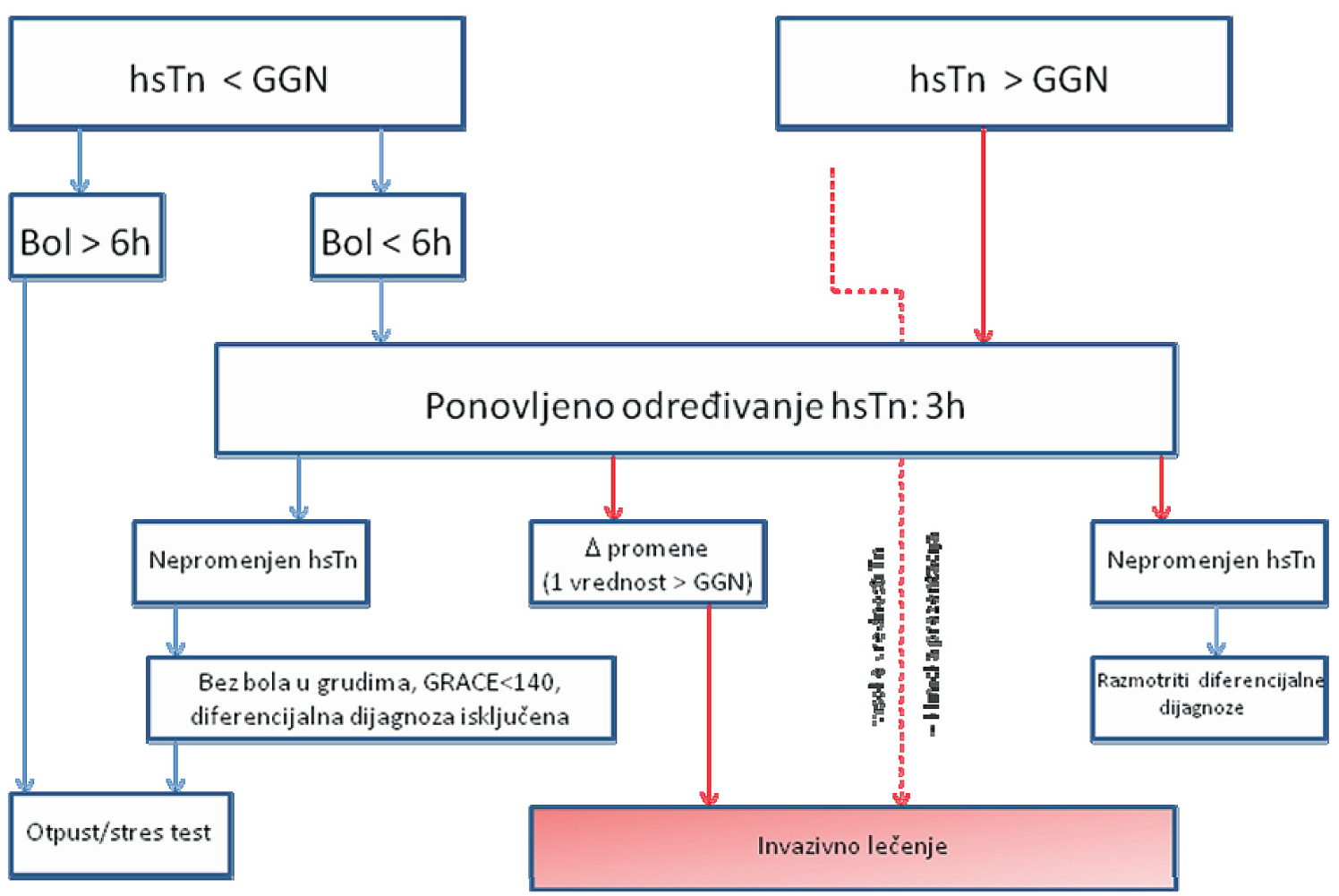

Grafikon 4. Brzo isključivanje AKS sa visoko senzitivnim troponinom

Tabela 3. Diferencijalna dijagnoza NSTE-AKS

\begin{tabular}{|c|c|c|c|c|c|}
\hline Kardiološka & Plućna & Hematološka & Vaskularna & Gastrointestinalna & Ortopedska/infekcije \\
\hline $\begin{array}{l}\text { Miokarditis } \\
\text { Perikarditis } \\
\text { Mioperikarditis } \\
\text { Kardiomiopatija } \\
\text { Valvularna bolest } \\
\text { Apikalno } \\
\text { baloniranje } \\
\text { Srčana trauma }\end{array}$ & $\begin{array}{l}\text { Embolija pluća } \\
\text { Infarkt pluća } \\
\text { Pneumonija } \\
\text { Pleuritis } \\
\text { Pneumotoraks }\end{array}$ & $\begin{array}{l}\text { Anemija } \\
\text { srpastih } \\
\text { ćelija }\end{array}$ & $\begin{array}{l}\text { Disekcija aorte } \\
\text { Aneurizma aorte } \\
\text { Koarktacija aorte } \\
\text { Cerebrovaskularne } \\
\text { bolesti }\end{array}$ & $\begin{array}{l}\text { Ezofagealni spazam } \\
\text { Ezofagitis } \\
\text { Peptični ulkus } \\
\text { Pankreatitis } \\
\text { Holecistitis }\end{array}$ & $\begin{array}{l}\text { Cervikalna diskopatija } \\
\text { Fraktura pršljena } \\
\text { Povreda/ } \\
\text { zapaljenje mišića } \\
\text { Kostohondritis } \\
\text { Herpes zoster }\end{array}$ \\
\hline
\end{tabular}

hsTn - visoko senzitivni troponin, GGN - gornja granica normale, 99-ti percentil zdrave populacije, $\Delta$-promena u zavisnosti od korišćenog testa

\section{Dijagnoza i procena rizika}

- Izdvaja se nekoliko kliničkih prezentacija NSTEAKS:

- Produženi (>20 minuta) anginozni bol u mirovanju

- Novonastala (de novo) angina

- Nedavna destabilizacija prethodno stabilne angine (crescendo angina)

- Postinfarktna angina

Dijagnoza NSTE-AKS nikada ne bi trebalo da bude postavljena samo na osnovu srčanih biomarkera, čije bi povišene vrednosti trebalo da budu razmatrane u kontekstu kliničkog nalaza. Ukoliko je prva vrednost troponina normalna, potrebno je ponoviti analizu za 6-9h. U NSTE-AKS, mala povećanja troponina se mogu registro- vati unutar 48-72h. Uvođenjem visoko senzitivnog troponina (hsTn) omogućeno je rano postavljanje dijagnoze i identifikacija osoba sa povećanim rizikom, primenom protokola za brzo isključivanje AKS (3h). Kopeptin je novi biomarker koji bi u kombinaciji sa troponinom još više povećao senzitivnost i specifičnost kod bolesnika sa ranom prezentacijom.

\section{Nekoronarna stanja sa povišenim troponinom}

- Teška kongestivna srčana insuficijencija - akutna ili hronična

- Disekcija aorte, aortna mana ili hipertrofična kardiomiopatija 
- Kontuzija miokarda, ablacija, pejsing, kardioverzija ili endomiokardna biopsija

- Inflamatorne bolesti, npr. miokarditis, ili miokardna ekstenzija endo-/pericarditisa

- Hipertenzivna kriza

- Tahi- ili bradiaritmije

- Embolija pluća, teška plućna hipertenzija

- Hipotireoidizam

- Sindrom apikalnog baloniranja

- Hronična ili akutna bubrežna insuficijencija

- Akutna neurološka bolest, uključujući šlog, ili subarahnoidalnu hemoragiju

- Infiltrativne bolesti, npr. amiloidoza, hemohromatoza, sarkoidoza, sklerodermija

- Toksično dejstvo lekova, npr. adriamicin, 5-fluorouracil, herceptin, zmijski otrov

- Opekotine, ukoliko zahvataju > 30\% površine kože

- Rabdomioliza

- Ugroženi bolesnici, naročito sa respiratornom insuficijencijom, ili sepsom

$\cup$ Tabeli 3. prikazana je diferencijalna dijagnoza kardioloških i nekardioloških stanja koja mogu da maskiraju NSTE-AKS.

\section{Skorovi rizika}

Nekoliko skorova za stratifikaciju rizika razvijeno je i ispitano na velikom broju bolesnika. GRACE (Global Registry of Acute Cardiac Events) skor rizika zasnovan je na velikoj neselektivnoj populaciji internacionalnih registara koji su obuhvatali čitav spektrum AKS bolesnika. Pomoću GRACE skora moguće je odrediti rizik za intrahospitalni mortalitet i mortalitet nakon 6 meseci (Tabele 4.4 i 4.5 ).

GRACE skor računa se sabiranjem numeričkih vrednosti datih u Tabeli 4.4 koje odgovaraju određenim kliničkim karakteristikama bolesnika. Numerička vrednost GRACE skora kreće se od 2 do 372.

(http://www.outcomes-umassmed.org/grace/acs_ risk/acs_risk_content.html)

\section{Skor rizika za krvarenje}

Krvarenje je udruženo sa lošom prognozom u NSTEAKS. Pomoću CRUSADE (Can Rapid risk stratification of Unstable angina patients Suppress ADverse outcomes with Early implementation of the ACC/AHA guidelines) skor rizika moguće je odrediti rizik za veliko krvarenje u
Tabela 4. Prediktori GRACE skor rizika

\begin{tabular}{|c|c|}
\hline \multicolumn{1}{|c|}{ Prediktor } & skor \\
\hline Starost (godine) & 0 \\
\hline$<40$ & 18 \\
\hline $40-49$ & 36 \\
\hline $50-59$ & 55 \\
\hline $60-69$ & 73 \\
\hline $70-79$ & 91 \\
\hline 80 &
\end{tabular}

Srčana frekvencija (otkucaj/min)

\begin{tabular}{|c|r|}
\hline$<70$ & 0 \\
\hline $70-89$ & 7 \\
\hline $110-149$ & 23 \\
\hline $150-199$ & 36 \\
\hline$>200$ & 46 \\
\hline
\end{tabular}

\begin{tabular}{|c|c|}
\hline \multicolumn{2}{|c|}{ Sistolni krvni pritisak $(\mathbf{m m H g})$} \\
\hline$<80$ & 63 \\
\hline $80-99$ & 58 \\
\hline $100-119$ & 47 \\
\hline $120-139$ & 37 \\
\hline $140-159$ & 26 \\
\hline $160-199$ & 11 \\
\hline$>200$ & 0 \\
\hline
\end{tabular}

\begin{tabular}{|c|c|}
\hline \multicolumn{2}{|c|}{ Kreatinin $(\mu \mathrm{mol} / \mathrm{L})$} \\
\hline $0-34$ & 2 \\
\hline $35-70$ & 5 \\
\hline 71-105 & 8 \\
\hline $106-140$ & 11 \\
\hline $141-176$ & 14 \\
\hline 177-353 & 23 \\
\hline$\geq 354$ & 31 \\
\hline \multicolumn{2}{|c|}{ Killip klasa } \\
\hline 1 & 0 \\
\hline II & 21 \\
\hline III & 43 \\
\hline IV & 64 \\
\hline Srčani zatoj pri prijemu & 43 \\
\hline Povišeni srčani markeri & 15 \\
\hline ST-segment promene & 30 \\
\hline
\end{tabular}

Tabela 5. Intrahospitalni i mortalitet nakon 6 meseci na osnovu GRACE skora rizika

\begin{tabular}{|l|c|c|}
\hline Kategorija rizika & GRACE skor rizika & Intrahospitalni mortalitet (\%) \\
\hline Nizak & $\leq 108$ & $<1$ \\
\hline Srednji & $109-140$ & $1-3$ \\
\hline Visok & $>140$ & $>3$ \\
\hline Kategorija rizika & GRACE skor rizika & Mortalitet nakon 6 meseci (\%) \\
\hline Nizak & $\leq 88$ & $3-8$ \\
\hline Srednji & $89-118$ & $>8$ \\
\hline Visok & $>118$ & $<$ \\
\hline
\end{tabular}


Tabela 6. CRUSADE skor rizika za krvarenje

Algoritam za određivanje CRUSADE skora rizika za veliko krvarenje u toku hospitalizacije

\begin{tabular}{|c|c|}
\hline Prediktor & Skor \\
\hline $\begin{array}{c}\text { Bazalni hematokrit, \% } \\
\qquad 31 \\
31-33.9 \\
34-36.9 \\
37-39.9 \\
\geq 40\end{array}$ & $\begin{array}{l}9 \\
7 \\
3 \\
2 \\
0\end{array}$ \\
\hline $\begin{array}{c}\text { Klirens kreatinina, } \mathrm{mL} / \mathrm{min} \\
\leq 15 \\
>15-30 \\
>30-60 \\
>60-90 \\
>90-120 \\
>120\end{array}$ & $\begin{array}{r}39 \\
35 \\
28 \\
17 \\
7 \\
0\end{array}$ \\
\hline $\begin{array}{c}\text { Srčana frekvencija (otkucaja/min) } \\
\leq 70 \\
71-80 \\
81-90 \\
91-100 \\
101-110 \\
111-120 \\
\geq 121\end{array}$ & $\begin{array}{r}0 \\
1 \\
3 \\
6 \\
8 \\
10 \\
11\end{array}$ \\
\hline Prediktor & Skor \\
\hline $\begin{array}{c}\text { Pol } \\
\text { Muškarci } \\
\text { Žene }\end{array}$ & $\begin{array}{l}0 \\
8\end{array}$ \\
\hline $\begin{array}{l}\text { Znaci SI pri prijemu } \\
\mathrm{Ne} \\
\mathrm{Da}\end{array}$ & $\begin{array}{l}0 \\
7\end{array}$ \\
\hline
\end{tabular}

toku hospitalizacije (www.crusadebleedingscore.org/) (Tabela 6. i Slika 1).

U Tabeli 7 prikazane su preporuke sa dijagnozu i stratifikaciju rizika kod bolesnika sa NSTE-AKS.

\begin{tabular}{|c|c|}
\hline \multicolumn{2}{|l|}{$\begin{array}{c}\text { Algoritam za određivanje CRUSADE skora rizika za veliko } \\
\text { krvarenje u toku hospitalizacije }\end{array}$} \\
\hline Prethodna vaskularna bolest & 0 \\
Ne & 6 \\
Da & \\
Dijabetes & 0 \\
Ne & 6 \\
Da & \\
$\leq 90$ & 10 \\
$91-100$ & 8 \\
$101-120$ & 5 \\
$121-180$ & 1 \\
$181-200$ & 3 \\
$\geq 201$ & 5 \\
\hline
\end{tabular}

CRUSADE skor rizika za krvarenje

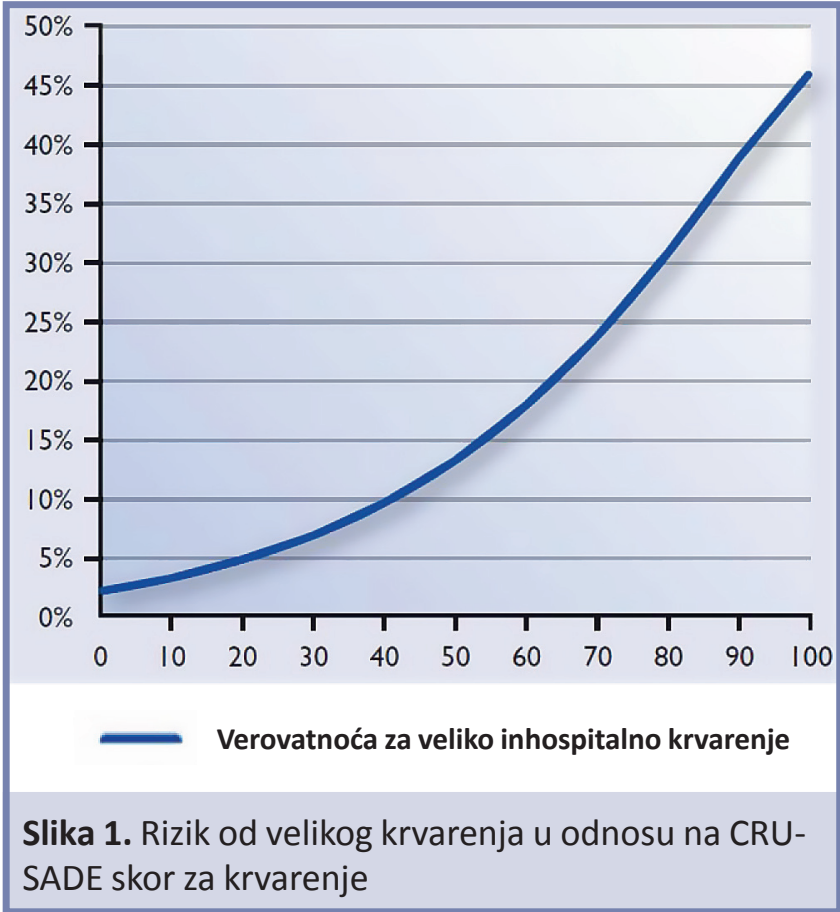

Tabela 7. Preporuke za dijagnozu i stratifikaciju rizika kod bolesnika sa NSTE-AKS ${ }^{8}$

\begin{tabular}{|l|c|c|}
\hline & $\begin{array}{c}\text { Klasa } \\
\text { preporuke }\end{array}$ & Nivo dokaza \\
\hline $\begin{array}{l}\text { Pacijente sa AKS treba primiti po mogućstvu u namensku jedinicu za bol u grudima ili koro- } \\
\text { narnu jedinicu. }\end{array}$ & I & C \\
\hline Preporučuje se korišćenje skorova rizika za prognozu i krvarenje (npr. GRACE, CRUSADE). & I & B \\
\hline $\begin{array}{l}\text { EKG treba snimiti unutar } 10 \text { minuta od prvog medicinskog kontakta. } \\
\text { EKG ponoviti u slučaju ponovnih simptoma, i posle 6-9 h i } 24 \text { h, i pre otpusta iz bolnice. }\end{array}$ & I & B \\
\hline $\begin{array}{l}\text { Odmah odrediti vrednosti troponina (cTnT ili cTnl). Rezultat treba da bude dostupan u roku } \\
\text { od } 60 \text { minuta. Test bi trebalo ponoviti 6-9 h posle prvog uzimanja ako je prvi nalaz negativan. } \\
\text { Ponoviti određivanje Tn nakon } 12-24 \text { h ako je kliničko stanje još uvek sugestivno na AKS. }\end{array}$ & I \\
\hline $\begin{array}{l}\text { Brzi protokol za isključivanje AKS (0 i 3h) se preporučuje kada su dostupni testovi za određi- } \\
\text { vanje visoko senzitivnog troponina (hsTn). }\end{array}$ & I \\
\hline $\begin{array}{l}\text { Ehokardiogram se preporučuje za sve pacijente da se ispita regionalna i globalna funkcija } \\
\text { leve komore i zbog diferencijalne dijagnoze. }\end{array}$ & I \\
\hline $\begin{array}{l}\text { Koronarografija je indikovana u pacijenata u kojih obim koronarne bolesti ili uzročna lezija } \\
\text { moraju biti određene. }\end{array}$ & B I \\
\hline $\begin{array}{l}\text { Pacijentima bez ponavljanih bolova, sa normalnim EKG nalazom, negativnim troponinima, i } \\
\text { niskim skorovima rizika, preporučuje se neinvazivni stres test za izazivanje ishemije pre odlu- } \\
\text { čivanja o invazivnoj strategiji. }\end{array}$ & I \\
\hline
\end{tabular}


Tabela 8. Preporuke za primenu antiishemijskih lekova kod bolesnika sa NSTE-AKS ${ }^{8}$

\begin{tabular}{|l|c|c|}
\hline & $\begin{array}{c}\text { Klasa } \\
\text { preporuke }\end{array}$ & $\begin{array}{c}\text { Nivo } \\
\text { dokaza }\end{array}$ \\
\hline $\begin{array}{l}\text { Nitrati efikasno ublažuju simptome anginoznih napada; intravenski nitrati se prepo- } \\
\text { ručuju u pacijenata sa ponavljanom anginom i/ili znacima srčane insuficijencije }\end{array}$ & I & C \\
\hline $\begin{array}{l}\text { Beta blokatori se preporučuju ukoliko ne postoje kontraindikacije, a naročito kod pa- } \\
\text { cijenata sa hipertenzijom ili tahikardijom }\end{array}$ & I \\
\hline $\begin{array}{l}\text { Blokatori kalcijumskih kanala dovode do ublažavanja simptoma kod pacijenata koji } \\
\text { već primaju nitrate i beta blokatore (dihidropiridinskog tipa) i u pacijenata sa kontra- } \\
\text { indikacijom za beta blokatore (tipa benzotiazepina ili feniletilamina). }\end{array}$ & I \\
\hline $\begin{array}{l}\text { Blokatori kalcijumskih kanala se preporučuju u pacijenata sa vazospastičnom angi- } \\
\text { nom. }\end{array}$ & I & B \\
\hline $\begin{array}{l}\text { Nifedipin, ili druge dihidropiridine, ne treba koristiti osim u kombinaciji sa beta bloka- } \\
\text { torima }\end{array}$ & III & B \\
\hline
\end{tabular}

Tabela 9. Preporuke za oralne antitrombocitne lekove kod bolesnika sa NSTE-AKS ${ }^{8}$

\begin{tabular}{|c|c|c|}
\hline & $\begin{array}{l}\text { Klasa } \\
\text { preporuke }\end{array}$ & $\begin{array}{l}\text { Nivo } \\
\text { dokaza }\end{array}$ \\
\hline $\begin{array}{l}\text { Aspirin se preporučuje svim pacijentima bez kontraindikacija u inicijalnoj dozi optere- } \\
\text { ćenja od } 150-300 \mathrm{mg} \text {, i kasnije u dozi održavanja od } 75 \mathrm{mg}-100 \mathrm{mg} \text { dnevno dugoročno } \\
\text { u zavisnosti od strategije lečenja. }\end{array}$ & 1 & $A$ \\
\hline $\begin{array}{l}\mathrm{P} 2 \mathrm{Y}_{12} \text { inhibitor trebalo bi dodati aspirinu što je pre moguće i nastaviti tokom } 12 \text { mese- } \\
\text { ci osim ako postoje kontraindikacije kao što je visok rizik od krvarenja. }\end{array}$ & 1 & $A$ \\
\hline $\begin{array}{l}\text { Inhibitori protonske pumpe (prvenstveno ne omeprazol) u kombinaciji sa dvojnom } \\
\text { antiagregacionom terapijom (DAT) preporučuje se u pacijenata sa istorijom gastroin- } \\
\text { testinalnog krvarenja ili peptičnog ulkusa, za pacijente sa drugim faktorima rizika (in- } \\
\text { fekcija Helicobacter pylori, starost preko } 65 \text { godina, istovremeno uzimanje antikoagu- } \\
\text { lanata ili steroida ). }\end{array}$ & 1 & $A$ \\
\hline $\begin{array}{l}\text { Produženo ili trajno isključivanje } \mathrm{P}_{2} \mathrm{Y}_{12} \text { inhibitora unutar } 12 \text { meseci posle uključivanja } \\
\text { ne savetuje se, osim ukoliko nije klinički indikovano. }\end{array}$ & 1 & C \\
\hline $\begin{array}{l}\text { Tikagrelor (180 mg doza opterećenja, } 90 \text { mg dva puta dnevno) preporučuje se u svih } \\
\text { pacijenata sa umerenim do visokim rizikom od ishemijskih događaja (npr. povišeni } \\
\text { troponini), bez obzira na počenu strategiju lečenja i uključujući one koji su prethodno } \\
\text { lečeni sa klopidogrelom koji bi trebalo prekinuti kada se počne sa tikagrelorom. }\end{array}$ & 1 & B \\
\hline $\begin{array}{l}\text { Prasugrel ( } 60 \text { mg doza opterećenja, } 10 \text { mg dnevna doza) preporučuje se za } \mathrm{P}_{2} \mathrm{Y}_{12} \text { inhi- } \\
\text { bicju kod pacijenata (posebno dijabetičara) u kojih je poznata koronarna anatomija i u } \\
\text { kojih se planira } \mathrm{PCl} \text { osim ako postoji visok rizik od životno ugrožavajućeg krvarenja ili } \\
\text { druge kontraindikacije. }\end{array}$ & 1 & B \\
\hline $\begin{array}{l}\text { Klopidogrel (300mg doza opterećenja, } 75 \mathrm{mg} \text { dnevna doza) preporučuje se za pacijen- } \\
\text { te koji ne mogu dobiti tikogrelor ili prasugrel. }\end{array}$ & I & A \\
\hline $\begin{array}{l}\text { Klopidogrel } 600 \text { mg doze opterećenja (ili dodatak } 300 \text { mg na } \mathrm{PCl} \text { posle inicijalnih } 300 \\
\text { mg doze opterećenja) preporučuje se za pacijente određene za invazivnnu strategiju } \\
\text { kada tikagrelor ili prasugrel nisu primenljivi. }\end{array}$ & 1 & B \\
\hline $\begin{array}{l}\text { Veću dozu održavanja klopidogrela od } 150 \text { mg dnevno trebalo bi razmotriti u prvih } \\
\text { sedam dana u pacijenata tretiranih sa PCl i bez povećanog rizika za krvarenje }\end{array}$ & Ila & B \\
\hline $\begin{array}{l}\text { Povećanje doze održavanja klopidogrela zasnovano na testiranju funkcije trombocita } \\
\text { se ne preporučuje rutinski, ali može biti razmatrana u pojedinačnim slučajevima. }\end{array}$ & Ilb & B \\
\hline $\begin{array}{l}\text { Genotipizacija i/ili testiranje funkcije trombocita može biti razmatrana u pojedinačnim } \\
\text { slučajevima kada se koristi klopidogrel. }\end{array}$ & IIb & B \\
\hline $\begin{array}{l}\text { U pacijenata lečenih sa } \mathrm{P}_{2 Y_{12}} \text { inhibitorima koji treba da se podvrgnu većoj elektivnoj } \\
\text { opreaciji (uključujući CABG), trebalo bi razmotriti odlaganje operacije za najmanje } 5 \\
\text { dana posle prekidanja tikagrelora ili klopidogrela i } 7 \text { dana za prasugrel, ako je klinički } \\
\text { izvodljivo i ako pacijent nije u visokom riziku za ishemijski događaj. }\end{array}$ & Ila & C \\
\hline $\begin{array}{l}\text { Kombinacija aspirina i NSAID (selektivni COX-2 inhibitori i neselektivni NSAID) ne pre- } \\
\text { poručuje se. }\end{array}$ & III & C \\
\hline
\end{tabular}




\section{Lečenje bolesnika sa NSTE-AKS}

Antiishemijski lekovi (Tabela 8) smanjuju miokardnu potrošnju kiseonika (smanjujući srčanu frekvencu, krvni pritisak ili kontraktilnost leve komore) i/ili deluju vazodilatatorno.

Antitrombocitnu terapiju (Tabele 9 i 10) trebalo bi uvesti što je ranije moguće po postavljanju dijagnoze NSTE-AKS kako bi se smanjio rizik od akutnih ishemijskih komplikacija i ponovnih aterotrombotičnih događaja. Trombociti mogu biti inhibirani sa tri vrste lekova: aspi-

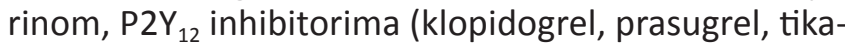
grelol) i glikoprotein Ilb/IIla inhibitorima.

Antikoagulantni lekovi (Tabela 11) se koriste u lečenju NSTE-AKS da spreče stvaranje ili aktivnost trombina, čime se smanjuje učestalost događaja povezanih sa stvaranjem tromba. Nekoliko antikoagulanasa koji delu- ju na različite nivoe koagulacione kaskade ispitivano je u NSTE-AKS. Postoje dokazi o većoj efikasnosti antikoagulanata kada se dodaju antiagregacionim lekovima, i da je ova kombinacija efikasnija nego kada se ove terapije primenjuju pojedinačno.

\section{Revaskularizacija miokarda}

Revaskularizacija miokarda kod bolesnika sa NSTEAKS ima za cilj oslobađanje od anginoznih tegoba, skraćenje boravka u bolnici i poboljšanje prognoze. Postavljanje indikacija i određivanje optimalnog vremena za revaskularizaciju miokarda, kao i izbor adekvatnog pristupa (PCl ili CABG) zavisi od mnogo faktora uključujući pacijentovo stanje, faktore rizika, komorbiditete, i ekstenzivnost i značajnost lezija otkrivenih na koronarnoj angiografiji. (Tabela 4.12).

Tabela 10. Preporuke za blokatore GP IIb/IIla receptora kod bolesnika sa NSTE-AKS ${ }^{8}$

\begin{tabular}{|c|c|c|}
\hline & $\begin{array}{l}\text { Klasa } \\
\text { preporuke }\end{array}$ & $\begin{array}{l}\text { Nivo } \\
\text { dokaza }\end{array}$ \\
\hline $\begin{array}{l}\text { Izbor kombinacije oralnih antiagregacionih lekova, GP IIb/IIla blokatora, i antikoagula- } \\
\text { nata trebalo bi praviti u odnosu na rizik od ishemijskih događaja i krvarenja. }\end{array}$ & I & C \\
\hline $\begin{array}{l}\text { Među pacijentima koji se već leče DAT, preporučuje se dodavanje GP IIb/IIla blokatora } \\
\text { za visoko rizične } \mathrm{PCl} \text { (povišen troponin, vidljiv tromb) ako je rizik od krvarenja nizak. }\end{array}$ & I & B \\
\hline $\begin{array}{l}\text { Dodavanje eptifibatida ili tirofibana aspirinu trebalo bi razmotriti pre angiografije u vi- } \\
\text { soko rizičnih pacijenata koji nisu prethodno primili dozu opterećenja } \mathrm{P}_{2} \mathrm{Y}_{12} \text { inhibitora. }\end{array}$ & Ila & C \\
\hline $\begin{array}{l}\text { U visoko rizičnih pacijenata dodavanje eptifibatida ili tirofibana uz DAT pre rane angi- } \\
\text { ografije trebalo bi razmotriti ukoliko postoji ishemija i ukoliko je rizik od krvarenja ni- } \\
\text { zak. }\end{array}$ & Ilb & $C$ \\
\hline $\begin{array}{l}\text { Blokatori GP IIb/IIla receptora se ne preporučuju rutinski pre angiografije u invazivnoj } \\
\text { strategiji lečenja. }\end{array}$ & III & A \\
\hline $\begin{array}{l}\text { Blokatori GP IIb/IIla receptora se ne preporučuju za pacijente na DAT koji se leče kon- } \\
\text { zervativno. }\end{array}$ & III & A \\
\hline
\end{tabular}

Tabela 11. Preporuke za antikoagulantnu terapiju kod bolesnika sa NSTE-AKS ${ }^{8}$

\begin{tabular}{|c|c|c|}
\hline & $\begin{array}{c}\text { Klasa } \\
\text { preporuke }\end{array}$ & $\begin{array}{c}\text { Nivo } \\
\text { dokaza }\end{array}$ \\
\hline $\begin{array}{l}\text { Antikoagulantna terapija uz dodatak antitrombocitne terapije preporučuje se u terapiji } \\
\text { svih pacijenta. }\end{array}$ & I & A \\
\hline Antikoagulantni lek treba izabrati na osnovu rizika od ishemije i krvarenja. & I & $\mathrm{C}$ \\
\hline $\begin{array}{l}\text { Fondaparin ( } 2.5 \mathrm{mg} \text { subkutano na dan) se preporučuje zbog najpovoljnijeg profila } \\
\text { efikasnost/sigurnost u odnosu na antikoagulante. }\end{array}$ & 1 & A \\
\hline $\begin{array}{l}\text { Ako je fondaparin inicijalni antikoagulant, jedan bolus UFH (85 IU/kg prilagođen ACT, ili } \\
60 \mathrm{IU} \text { u slučaju prateće primene GP IIb/IIla blokatora) treba dodati u vreme PCl. }\end{array}$ & 1 & B \\
\hline Enoksaparin (1mg/kg dva puta dnevno) se preporučuje kada fondaparin nije dostupan. & I & B \\
\hline $\begin{array}{l}\text { Ako fondaparin ili enoksaparin nisu dostupni, indikovani su UFH sa ciljnim vrednostima } \\
\text { aPTT od 50-70 s ili drugi LMWH u odgovarajućim preporučenim dozama. }\end{array}$ & 1 & $\mathrm{C}$ \\
\hline $\begin{array}{l}\text { Bivalirudin sa GP IIb/IIIa blokatorima se preporučuje kao alternativa UFH sa GP IIb/IIla } \\
\text { blokatorima u pacijenata kojima je namenjena hitna ili rana invazivna strategija, posebno } \\
\text { u pacijenata sa visokim rizikom od krvarenja. }\end{array}$ & 1 & B \\
\hline Kod konzervativne strategije, antikoagulansi se mogu primenjivati sve do otpusta iz bolnice. & 1 & A \\
\hline $\begin{array}{l}\text { Prekidanje antikoagulantne terapije trebalo bi razmotriti posle završene invazivne } \\
\text { procedure osim ako nije drugačije indikovano. }\end{array}$ & Ila & $\mathrm{C}$ \\
\hline Ukršteno davanje heparina (UFH i LMWH) se ne preporučuje. & III & B \\
\hline
\end{tabular}


Tabela 12. Preporuke za revaskularizaciju kod bolesnika sa NSTE-AKS ${ }^{8}$

\begin{tabular}{|l|c|}
\hline \multicolumn{1}{|c|}{$\begin{array}{c}\text { Klasa } \\
\text { preporuke }\end{array}$} & $\begin{array}{c}\text { Nivo } \\
\text { dokaza }\end{array}$ \\
\hline $\begin{array}{l}\text { Invazivni pristup (unutar 72 h) je indikovan kod pacijenata sa: } \\
\text { panavljanim simptomima }\end{array}$ & I \\
\hline $\begin{array}{l}\text { Hitna koronarografija (<2 sata) se preporučuje kod pacijenata sa vrlo visokim } \\
\text { ishemičnim rizikom (refraktarnom anginom, sa udruženom srčanom insuficijencijom, } \\
\text { životno ugrožavajućim ventrikularnim aritmijama, ili hemodinamskom nestabilnošću). }\end{array}$ & I \\
\hline $\begin{array}{l}\text { Rani invazivni pristup (<24 sata) je indikovan kod pacijenata sa GRACE skorom > 140 ili sa } \\
\text { bar jednim primarnim kriterijumom visokog rizika. }\end{array}$ & I \\
\hline $\begin{array}{l}\text { Neinvazivna potvrda ishemije preporučuje se kod pacijenata sa niskim rizikom bez } \\
\text { ponavljanja simptoma pre odlučivanja za invazivno ispitivanje. }\end{array}$ & C \\
\hline $\begin{array}{l}\text { Strategiju revaskularizacije (ad-hoc PCI uzročne lezije/višesudovna PCl/CABG) treba } \\
\text { bazirati na kliničkom statusu, težini bolesti, tj. rasprostranjenosti i angiografskim } \\
\text { karakteristikama lezija (tj. SYNTAX skor), u skladu sa lokalnim protokolom „tima za srce” }\end{array}$ & I \\
\hline $\begin{array}{l}\text { Pošto ne postoje stavovi o bezbednosti DES u AKS, primena DES bazira se na } \\
\text { individualnom pristupu u zavisnosti od osnovnih karakteristika, koronarne anatomije i } \\
\text { rizika od krvarenja. }\end{array}$ & I \\
\hline \begin{tabular}{l} 
Ne preporučuje se PCl za nesignifikantne lezije. \\
\hline Ne preporučuje se rutinsko invazivno ispitivanje kod niskorizičnih bolesnika.
\end{tabular} & C \\
\hline
\end{tabular}

\section{Kriterijumi za visok rizik sa indikacijom za invazivno lečenje}

\section{Primarni}

- Značajan porast ili pad troponina

- Dinamične promene u ST i T segmentu (simptomatske ili neme)

\section{Sekundarni}

- Dijabetes mellitus

- Bubrežna insuficijencija $\left(\mathrm{eGFR}<60 \mathrm{ml} / \mathrm{min} / 1.73 \mathrm{~m}^{2}\right)$

- Smanjena fukcija LK (EF <40\%)

- Rana postinfarktna angina
- Nedavna PCl

- Prethodna CABG

- Srednji do visok GRACE skor rizika

\section{Dugoročno lečenje (sekundarna prevencija) akutnih koronarnih sindroma}

Dugoročno lečenje (sekundarna prevencija) podrazumeva higijensko dijetetski režim i medikamentnu terapiju sa ciljem da se kontroliše svaki faktor rizika koji utiče na udaljenu prognozu bolesnika posle AKS, i neophodno lečenje komplikacija AKS-a.

Tabela 13. Preporuke za dugoročno lečenje bolesnika sa NSTE-AKS

\begin{tabular}{|c|c|c|}
\hline & $\begin{array}{c}\text { Klasa } \\
\text { preporuke }\end{array}$ & $\begin{array}{l}\text { Nivo } \\
\text { dokaza }\end{array}$ \\
\hline $\begin{array}{l}\text { Beta blokatore treba dati svim pacijentima sa smanjenom sistolnom funkcijom LK (EF } \\
\leq 40 \% \text { ). }\end{array}$ & I & $A$ \\
\hline $\begin{array}{l}\text { ACE inhibitori su indikovani unutar } 24 \mathrm{~h} \text { kod svih pacijenata sa } \mathrm{EF} \leq 40 \% \text { i kod pacijenata } \\
\text { sa srčanom insuficijencijom, dijabetesom, hipetenzijom ili hroničnom bubrežnom } \\
\text { insuficijencijom, u odsustvu kontraindikacija. }\end{array}$ & I & $A$ \\
\hline $\begin{array}{l}\text { ACE inhibitori se preporučuju i kod svih drugih pacijenata u cilju prevencije ponovne } \\
\text { pojave ishemije. Preporučeni su preparati i doze koje imaju dokazanu efikasnost. }\end{array}$ & I & B \\
\hline $\begin{array}{l}\text { Blokatore angiotenzinskih receptora treba razmotriti kod pacijenata koji ne tolerišu } \\
\text { ACE inhibitore. Preporučeni su preparati i doze koje imaju dokazanu efikasnost. }\end{array}$ & I & B \\
\hline $\begin{array}{l}\text { Antagoniste aldosteronskih receptora sa eplerenonom treba razmotriti kod bolesnika } \\
\text { nakon IM koji su već na terapiji sa ACE inhibitorima i beta blokatorima i koji imaju } \\
\mathrm{EF} \leq 35 \% \text { i dijabetes ili srčanu insuficijenciju, bez značajne bubrežne insuficijencije } \\
\text { (sCr }>221 \mu \mathrm{mol} / \mathrm{L}(>2.5 \mathrm{mg} / \mathrm{dL}) \text { za muškarce i }>177 \mu \mathrm{mol} / \mathrm{L}(>2.0 \mathrm{mg} / \mathrm{dL}) \text { za žene ili } \\
\text { hiperkalemije. }\end{array}$ & 1 & $A$ \\
\hline $\begin{array}{l}\text { Preporučuje se terapija statinima za snižavanje lipida sa ciljnom vrednosti LDLc }<1.8 \\
\mathrm{mmol} / \mathrm{l}(<70 \mathrm{mg} / \mathrm{dL} \text { ) odmah po prijemu bolesnika. }\end{array}$ & I & B \\
\hline
\end{tabular}




\section{Literatura:}

1. Ostojić M., Jancev M., et al. Protokol za prehospitalnu dijagnostiku i terapiju akutnog koronarnog sindroma. 2010, Beograd, Medicinski fakultet Univerziteta u Beogradu

2. Van de Werf F., et al. Management of acute myocardial infarction in patients presenting with persistent ST-segment elevation: the Task Force on the Management of ST-Segment Elevation Acute Myocardial Infarction of the European Society of Cardiology. Eur Heart J 2008; 29 (23): 2909-45.

3. Busk M., et al. Infarct size and myocardial salvage after primary angioplasty in patients presenting with symptoms for $<12 \mathrm{~h}$ vs. 12-72 h. Eur Heart J 2009; 30 (11): 1322-30.

4. Schomig A., et al. Mechanical reperfusion in patients with acute myocardial infarction presenting more than 12 hours from symptom onset: a randomized controlled trial., JAMA 2005; 293 (23): 2865-72.
5. Hochman JS, et al. Coronary intervention for persistent occlusion after myocardial infarction, N. Engl J. Med 2006; 355 (23): 2395-407.

6. Steg PG, et al. DECOPI (DEsobstruction COronaire en Post-Infarctus): a randomized multi-centre trial of occluded artery angioplasty after acute myocardial infarction, Eur Heart J., 2004; 25 (24): 2187-94.

7. Wijns W, et al. Guidelines on myocardial revascularization: The Task Force on Myocardial Revascularization of the European Society of Cardiology (ESC) and the European Association for CardioThoracic Surgery (EACTS), Eur Heart J., 2010; 31 (20): 2501-55.

8. Hamm CW, et al. ESC Guidelines for the management of acute coronary syndromes in patients presenting without persistent ST-segment elevation: The Task Force for the management of acute coronary syndromes (ACS) in patients presenting without persistent ST-segment elevation of the European Society of Cardiology (ESC), Eur Heart J., 2011; (in press) 